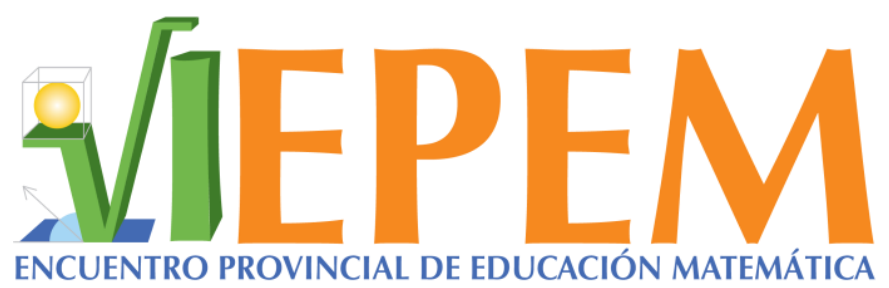

VI Encuentro Provincial de Educación Matemática.

27 al 29 de setiembre, 2017. Puntarenas, Costa Rica.

\title{
Animales en peligro de extinción en Costa Rica como fuente de creación de problemas de probabilidad
}

\author{
Lorena Salazar Solórzano \\ lorena.salazar.solorzano@una.cr \\ Universidad Nacional \\ Costa Rica
}

\begin{abstract}
Resumen
Costa Rica conserva aproximadamente 13.000 kilómetros cuadrados en parques y reservas nacionales, con una riqueza y variedad invaluable en flora y fauna. Sin embargo, esto no ha impedido el aumento de especies en peligro de extinción. Este taller busca que los profesores logren, por un lado, concientizar a sus estudiantes de esta problemática, mientras que, por otro lado, inventen problemas para la enseñanza de los contenidos de probabilidad establecidos en los Programas de Estudio de Matemática vigentes en Costa Rica. Así mismo se espera que los docentes, usen este modelo de buscar temas de preocupación nacional, que refuercen los ejes transversales con otras asignaturas (ciencias, estudios sociales), tendientes a formar ciudadanos consientes y con responsabilidad patriótica de conservar la naturaleza.
\end{abstract}

Palabras clave: creación de problemas; animales en extinción; educación matemática; probabilidad.

\section{Introducción}

Los Programas de Estudio de Matemática en Costa Rica, declaran la resolución de problemas como el enfoque principal de enseñanza, razón por la cual los docentes deben ser competentes, no solo en resolver problemas, sino también en crear problemas de calidad, que sean llamativos, contextualizados y que respondan a un objetivo de estudio. Según Mallart, Font y Malaspina (2015), los profesores tienden a asumir que ellos siempre dispondrán de otras fuentes para proveerse de problemas para plantear a sus futuros estudiantes. Por otro lado, el filósofo, político y educador Paulo Freire, mencionado por Ellerton y Cai (2015, p.vii), señala que las masas oprimidas deben comprometerse, en la praxis, para su transformación, de modo que, según su criterio, involucrar a los estudiantes

Taller

\footnotetext{
Salazar. L. (2017). Animales en peligro de extinción en Costa Rica como fuente de creación de problemas de probabilidad. En Y. Morales-López, M. Picado, R. Gamboa, C. Martínez, M. Castillo y R. Hidalgo (Eds.), Memorias del VI Encuentro Provincial de Educación Matemática, Costa Rica, 2017 (pp. 52-54). Heredia: Universidad Nacional. ISBN: 978-9968-9661-5-3. DOI: http://dx.doi.org/10.15359/epem.6.14
} 
y profesores en formación en tareas de creación de problemas, desarrolla miembros y ciudadanos más democráticos, diversos y con pensamiento crítico necesario en la sociedad.

Es de interés de este taller lograr una transformación en los ciudadanos costarricenses, dado que según Lenin Corrales "las tasas actuales de extinción son las más altas de los registros históricos amenazando los valiosos servicios de los ecosistemas y con ello comprometiendo además el bienestar humano".

\section{Objetivo del taller}

Inducir a los docentes a crear problemas de probabilidad, usando como foco el tema de animales en peligro de extinción en Costa Rica, que ofrezcan material contextualizado para desarrollar, tanto los contenidos matemáticos como espacios de reflexión que concienticen a los jóvenes de esta problemática nacional.

\section{Metodología del taller}

Se iniciará con un video alusivo a la problemática de especies en extinción en Costa Rica. Se seguirán las etapas planteadas en Salazar (2016) para crear problemas de calidad, para luego exponerle algunos ejemplos propuestos relativos al tema de especies en extinción. En la sesión 2 se les suministrará unas fichas con imágenes e información de varios animales en extinción para que ellos creen problemas. En una última etapa se socializarán los resultados y se les pedirá reflexionar sobre otras problemáticas nacionales. Que podrían utilizarse para crear sus problemas. Se muestra un ejemplo alusivo:

Problema 1:

Una ONG ofrece presupuesto para diseñar un plan de protección que incluya tres mamíferos en peligro de extinción escogidos al azar.

a) ¿De cuantas maneras diferentes puede llevarse a cabo el proyecto?

b) ¿Cuál es la probabilidad de que en esta tripleta salga escogido un ave, un mamífero y un reptil?

\section{Resultados esperados}

Se espera que los profesores planteen problemas de interés, desde muy simples a más complejos, logrando así un empoderamiento docente que les de confianza en sus propias creaciones. A su vez, se espera que ellos mismos planteen temas de interés para posibles fuentes de creaciones que formen ciudadanos responsables, mientras aprenden contenidos matemáticos. 


\section{Referencias}

Corrales, Lenin. (2016). Especies Globalmente Amenazadas en Costa Rica. Recuperado de https://lenincorrales.com/2016/12/21/especies-globalmente-amenazadas-en-costarica-2016/

Mallart, A., Font, V. \& Malaspina, U. (2015). Reflexión sobre el significado de qué es un buen problema en la formación inicial de maestros. Perfiles Educativos. 38(152), 1430.

Salazar, L. (2016). Creación de problemas mediante un proceso guiado de cuatro etapas. Revista del CIDUI. Núm. 3. Recuperado de http://www.cidui.org/revistacidui/index.php/cidui/article/view/983/949

Singer, F., Ellerton, N \& Cai, J. (2015). Mathematical problem posing from research to effective Practice. Springer International Publishing.

\section{(c) (i) $\Theta$}

Esta obra está bajo una licencia de Creative Commons Reconocimiento-NoComercialSinObraDerivada 4.0 Internacional. 